\title{
СИСТЕМА
}

\section{И ВЗАИМОАЕЙСТВИЯ}

\author{
Анарюшин С. В.
}

\section{ПРОЦЕССЫ ВОЕННОЙ ИНТЕГРАЦИИ В ЕВРОПЕЙСКОМ СОЮЗЕ С ТОЧКИ ЗРЕНИЯ ТЕОРИИ НЕОРЕААИЗМА}

\begin{abstract}
Аннотация. Объектом данного исследования являются процессы военной интеграции в ЕС, которые рассматриваются сквозь призму теории неореализма. После окончания холодной войны и распада биполярной системымеждународных отношений неореализм отошёл на второй план в исследованиях безопасности. Новые угрозы и их восприятие требовали свежего взгляда на субъекты и объекты безопасности. Новые теории и подходы вышли на авансиену в исследованиях международных отношений и безопасности. Способность неореализма дать своё объяснение новым явлениям в Европе была поставлена под вопрос, а его вклад в оченку военной интеграции был крайне скудным. В данном исследовании особое внимание уделяется концепциям и гипотезам неореализма. Их прикладное применение в анализе Общей политики безопасности и обороны Европейского Союза способно пролить свет на природу интеграционных явлений и процессов. Теоретическая оченка прочессов военной интеграции объясняется необходимостью определить движущие силь, характер и предпочтения государств-членов, чтобы иметь возможность прогнозировать дальнейших ход ее развития. Методологическую и теоретическую основу данного исследования составляют системный подход к изучению научных трудов теоретиков неореализма и прикладной анализ процессов военной интеграции в ЕС с точки зрения основных постулатов и гипотез теории. Новизна исследования заключается в применении теории неореализма к интеграционным процессам в области обороны и безопасности в Европейском Союзе. Основными выводами проведенного исследования являются: 1) процессы военной интеграчии в Европейском Союзе укладываются в логику и концепиии неореализма, поскольку носят межправительственный характер, а интересы государств совпадают в очень ограниченном поле; 2) неореализм ограничен в определении степени влияния институтов на приоритеты государств, что, в случае с Общей политикой безопасности и обороны, базирующейся на институциональном сотрудничетве, сужает проблемное поле исследования; 3) несмотря на то, что страны ЕС продолжают полгаться на НАТО в вопросах колиективной обороны, появление новых угроз и схожесть их восприятия в ЕС, вероятно, будет способствовать углублению интеграции в области безопасности и обороны.
\end{abstract}


Ключевые слова: теория неореализма, национальные интересы, Европейский Союз, интеграция, европейскал безопасность, Европейское оборонное агентство, общие ресурсы, международнал безопасность, национальные государства, оборонный потенциал.

Review. The object of this research is the processes of military integration in the EU, which are being viewed through the prism of the theory of neorealism. After the end of the cold war and the collapse of the bipolar system of international relations neorealism has moved to a secondary position in the research on security. New threats and their perception required a fresh look at the subjects and objects of security. The new theories and approaches have taken the center stage within the research of international relations and security. A special attention is given to the concepts and hypotheses of neorealism. Their applied use the Common Foreign and Security Policy of the European Union in the analysis allows us to shed light upon the nature of integrational phenomena and processes. The theoretical assessment of the processes of military integration is explained by the necessity to determine the driving force, character and preferences of the member-states, in order to be able to forecast the future vector of its development.

Keywords: Theory of neorealism, National interests, European Union, Integration, European security, European Defense Agency, Common resources, International security, Member-states, Defense potential.

\section{ТЕОРЕТИЧЕСКИЕ}

\section{ГРАНИЦЫ НЕОРЕААИЗМА}

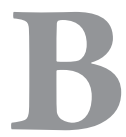

1979 году с выходом книги Кеннета Уолтца «Теория межАунароАной по$\Lambda$ итики» зародимась новая теория, которая привлекла большое внимание научных кругов и породила очереАную серию научных споров о природе межаународных отношений. Неореализм стал Аоминирующим поАхоАом в межАународных отношениях, поскольку он иогически объясня границы сотруАничества межАу государствами и вписывацся в контекст биполярного мира. Аальнейшие разработки теории и сравнение международных отношений с макроэкономическими модемями показали схожие черты межАу повеАением государств и экономических еАиниц (фирм) в иерархическом экономическом поряаке. Основным посылом Уолтца явцяется то, что состояние войны среАи госуАарств явАяется естественным состоянием. ${ }^{[1, p .173]}$ Этот аргумент не отиичается от классического реамизма и несёт в себе тот же смысл, что государства не могут Аоверять Аруг Аругу и Аолжны развивать свою собственную безопасность и оборону, чтобы защищать себя от Аругих. ОАнако Кеннет Уолтц не просто скопировац основные постулаты реализма, но развик их, чтобы они быми более алаптированными к реалиям современного мира. Уолтц утвержАает, что мы живём в мире анархии, но анархия не является чем-то Аанным, а стала результатом отсутствия мирового правитемьства или государства-арбитра, гАе «никто не имеет права командовать, никто не обязан подчиняться». $[1, \mathrm{p} .88]$

Неореалисты не проводят различий межАу межАународными отношениями и межАународной политикой, что с критической точки зрения выглядит, как ограничение аналитических возможностей теории. Они считают, что политика является еАинственной детерминантой в межАународных отношениях и игнорируют важность экономических, социальных и Аругих факторов. Стефано Гуццини подчёркивает, что Уолтц опреАеляет искцючительное пространство Аля исслеАОвателя в области межАународных отношений

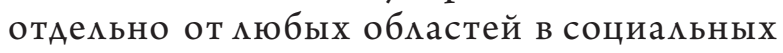
науках. ${ }^{[2, p .124]}$ Это преАположение способствует кучшему пониманию критики в сторону неореацизма с точки зрения Аругих теоретических течений.

В современном мире государства играют важную роль, поскольку они кучше приспособлены к выживанию в гоббсовском мире. ${ }^{[1, p .178]}$ Государства Аолжны опираться на самих себя, Аабы обеспечить свою безопасность, потому что основным Авижущим мотивом Аля выживания явцяются его национацьные интересы. В этих обстояте ьствах могущество явцяется основной «валютой» в межАунароАной политике, поскольку оно гарантирует выживание государства. Важно отметить, что существуют расхожАения межАу неореалистами в отношении номинала этой «вацюты». В отличие 
от Уолтца, который утвержАает, что безопасность является основной целью мюбого госуАарства, Ажон Мершаймер придерживается классического воззрения реализма, что именно могущество явмяется основным бцагом государств, которые будут агрессивно Аобиваться его укрепления, чтобы упреАить угрозы, исходящие от равных им конкурентов. ${ }^{[3, p .22]} \mathrm{He}$ смотря на разАичия в инструментах, которые позволяют государствам обеспечивать свои национальные интересы, все неореалисты имеют общий взгляА на «пункт назначения» внешней политики - обеспечить государству кучшую позицию на мировой арене. . 2, .135] $^{2}$

Аругой основопомагающей концепцией неореализма является «балансирование». ВвиАу постоянной угрозы выживанию в условиях анархии, государства будут стремиться балансировать межАу относительно равными по симе соперниками посреАством имитации (что можно набцюдать в процессе их социамизации), посреАством наращивания своих внутренних ресурсов (внутреннее балансирование) или посредством созАания альянсов с Аругими государствами (внешнее балансирование).$^{[3, p .156]}$

Таким образом, Аля обеспечения своей безопасности и увеличения своего могущества государства могут создавать альянсы или прибегать к Аругим способам сотрудничества, которые позволяют им преследовать свой главный интерес - повышение безопасности. Аля этих цемей государства примагают все необходимые усимия, которые помогают им укрепить свою собственную безопасность и ослабить могущество Аругих. Эти усилия можно разАелить на Аве категории: внутренние (шаги по увеличению экономического потенциа аа, усимению военной мощи, развитию инновационных стратегий) и внешние (шаги по укреплению ими расширению собственного ацьянса или ослаблению и ограничению возможностей ацьянса противоборствующей стороны. ${ }^{[1, p .118]}$

ОАнако неореалисты не ограничивают сосуществование государств созАанием различных моделей сотрудничества. Они также разработали принцип побеАившей стороны (bandwagoning), объясняющий, как государства Аействуют, когАа они не способны обес- печить безопасность своими собственными силами. Bandwagoning означает, что государства вступают в более сильный и влияте ьный альянс с целью обеспечения своей собственной безопасности. ${ }^{[1, p .119]}$

Экономические и политические достижения, совершенные Европейским Союзом, Аемонстрируют, что процесс интеграции может быть успешным и приеммемым Аля национальных государств. Несмотря на противоречащую могике неореализма природу интеграционного процесса, они преАложили свой собственный взгляА на этот феномен. Генри Киссинажер объясням причины европейской интеграции тем, что никто из прежних сторонников raison d'état в Европе не явцяется Аостаточно сильным, чтобы действовать в качестве хозяина зарожАающегося межАународного порядка. Они пытаются компенсировать свою относите ьную слабость созАанием еАИной Европы, и это усимие поглощает большую часть их энергии. ${ }^{[4, p .24]}$

Критики неореализма утвержАают, что это объяснение является недостаточно убеАите ьным и последовательным в связи с отсутствием глубокого анализа и игнорированием Аругих компонентов, которые опреАемяют условия, позволяющие государствам интегрироваться. Структуралисты и институционалисты соглашаются, что могика суверенитета всё ещё сохраняет свою силу и в большой степени объясняет поведение государств и опреАеляет их преАпочтения. ОАнако неореалисты игнорируют важность и влияние институтов, режимов и илей в межАународных отношениях. С момента окончания Второй мировой войны мир кардинально изменился. Международное право и институты вместе с национацьными госуАарствами расширили пространство безопасности, вкцючая в него новые субъекты и объекты, меняя традиционное понимание того, что является безопасностью и к кому она относится. Стив Смит указывает на тот факт, что за послеАние 30 мет исследования безопасности существенно эволюционировали, в то время как реализм отошел на второй план в этих исследованиях, поскольку Аругие течения преуспели в разработке новых концепций, которые подорвали позиции неореализма и сАелали их объектом широких Аискуссий. ${ }^{[5, \mathrm{p} .97]}$ 
Неореализм был проверен на прочность временем в связи с возникновением нового мирового поряАка, гАе после окончания холоАной войны на смену традиционному «балансированию» межАу Авумя блоками пришло более тесное сотруАничество межАу государствами. Эти побудитемьные мотивы, которые толкали интеграционные процессы по всему миру, проистекают из тех угроз, которые стами характерными Аля периода после окончания холодной войны. ГосуАарства не могут отвечать на эти вызовы в одиночку, поэтому они вынуждены объединять свои усилия, чтобы быть способными бороться с такими глобамьными проблемами, кактерроризм, эпидемии, распространение оружия массового уничтожения, нехватка энергоносителей и Ар. Основные критики неореализма соглашаются с тем фактом, что суверенитет остаётся кцючевым эмементом в международных отношениях. ОАнако они спорят, что он не явцяется опреАеляющим фактором в глобальной политике. Суверенитет будет ограничен, но функционален. Он перестанет быть всеобъемлющим и статичным, как это бымо при вестфацьской модели, считают критики неореализма. ${ }^{[6, p .52]}$

Неореалисты также критикуются за их чрезмерную сосредоточенность на государственных интересах, которые воспринимаются ими как нечто данное (exogenous good). Конструктивисты считают, что неореалисты игнорируют такие факторы, как идентичности и не принимают их во внимание в своём анамизе. ОАнако многие согласны, что основной Авижущей симой обеспечения безопасности, которая определяет его содержание и наАлежащие инструменты, явияется внутренняя могика государства. ${ }^{[7, \mathrm{p} .21]}$

В своём анализе политики великих Аержав, как главных сил, опреАемяющих глобаньную повестку Аня, Кеннет Уолтц показал в качестве примера процессы, которые изменяют поведение государств. Они характеризуются появлением новых угроз, которые заставляют государства изменять их внешнюю политику и преАпочтения. Этот феномен называется взаимозависимостью и демонстрирует, что государства Аолжны сотруАничать Аля того, чтобы обеспечить свою безопасность. Не только великие Аержавы, формирующие мировой порядок, но и межАународная конъюнктура также оказывает вмияние на поведение государств. ОАнако по мнению Кеннета Уолтца, это влияние явцяется ограниченным, потомучто государства остаются рационацьными. Пробцема не в том, как управцять миром, в том числе его крупными державами, а как великие Аержавы могут конструктивно испо ьзовать свои возможности по вциянию на межАународные отношения в зависимости от системных изменений. ${ }^{[1, p .210]}$

В своей теории Кеннет Уолтц применяет модель рыночной экономики, которая служит своеобразной моделью межАународных отношений. Макроэкономическая теория созАает базу Аля ПоАхода Уолтца к межАУнародной политике, потому что он провоАит аналогию межАу еАиницами (компаниями), взаимодействующими в иерархическом экономическом порядке и государствами на международной арене. Уолтц утвержАает, что существует взаимозависимость межАу экономическими субъектами из-за их разАичий, которые Аают основание Аля разделения труда. ОАнако взаимозависимость межАу госуАарствами отличается от взаимозависимости межАу компаниями, потому что в межАународной анархической системе государства остаются схожими. Несмотря на это, Уолтц преАполагает, что существует разница межАу возможностями

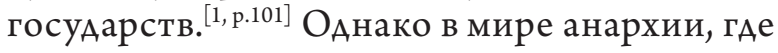
нет никаких правик такой сложный институт, как рынок не может существовать. ${ }^{[2, p .141]}$ Эта оценка демонстрирует слабость неореализма, однако, её не следует принимать на веру, поскольку рынок порой функционирует гораздо анархичнее, нежеки международные отношения.

Теория, разработанная Кеннетом Уолтцем в 1979 году, в опреАеленной степени устарела за последние 35 мет. Новые вызовы и угрозы, а также илеи породими беспрецеАентный феномен в мировой истории. Интеграционные процессы по всему миру ста$\Lambda$ и серьезным вызовом Аля неореализма, чья способность объяснить эти процессы быма поставцена поА вопрос. После окончания хо-

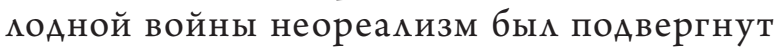
проверке на прочность, которая выявима его неспособность ответить на вопросы, встав- 
шие переА исследоватемями в области безопасности в эпоху постмодерна. Темне менее, неореализм содержит цемый спектр ценных иАей, которые могут служить основой Аля анализа интеграционныхпроцессов в Европе, Ааже в такой чувствитемьной Аля государств сфере, как безопасность и оборона.

\section{КОНЦЕПТУААЬНЫЕ ОСНОВЫ НЕОРЕА ИИЗМА И ТЕОРЕТИЧЕСКОЕ ОСМЫСАЕНИЕ ВОЕННОЙ ИНТЕГРАЦИИ В ЕС}

Уомтц полагает, что интересы или интеграция, основанные на аккумумировании общих ресурсов, не могут быть преАпосылками Аля устойчивых институционамизированных форм сотруаничества, поскомьку международные отношения остаются анархичными, а государства стремятся выжить, нежели быть поглощенными системной Аинамикой. ${ }^{[2, p .141]}$ У государств есть национамьные интересы, которые вынужАают их искать эффективные инструменты, чтобы реализовывать свои интересы. Если главным благом Аля государств явцяется безопасность, то они стремятся максимизировать свои возможности с тем, чтобы усимить национамьную безопасность.

С окончанием хомодной войны военная безопасность перестала быть Аоминирующим направлением, т.к. обостримись новые вызовы и угрозы, которые были Авижимы изменяющейся межАунароАно-политической конъюнктурой. МежАународный терроризм, организованная преступность, экстремизм, распространение оружия массового уничтожения преАстав яют угрозу Аля многих госуАарств и вынужАают их Аействовать сообща. Этиполитические условия меняют повеАение государств и их приоритеты на международной арене, а также требуют от них созАание новых инструментов, которые бы позвомими им преодолеть эти вызовы.

Временная интеграция и сближение интересов в теории Уомтца становятся возможными бцагодаря схожему восприятию угроз и необходимости наращивания возможностей Аля их нейтрамизации. Уомтц помагает, что главной заботой госуАарств явмяется не максимизация своей мощи, а поААержание своей позиции в системе. Основной целью в этой системе явмяется безопасность. ${ }^{[1, p .126]}$ Таким образом, государства пытаются аАаптироваться к Аанной межАунароАной окружающей среАе и испомьзовать её Аля того, чтобы усимить свою безопасность. Намичие разнообразныхугроз безопасности вынужАает государства Аействовать в самых разных сферах безопасности, если они хотят сохранить ими улучшить свое место в системе и структурах межАународной безопасности. ПараАигму Уомтца об интересе госуАарств в поААержании своих позиций в системе развивает Александр ЗиАшлаг, который помагает, что госуАарства стремятся использовать изменения в межАународных структурах и процессах с тем, чтобы занять такое положение в межАународной системе, которое позволяет им максимизировать их безопасность в существующей Аиверсификации современных угроз безопасности, государства выну-

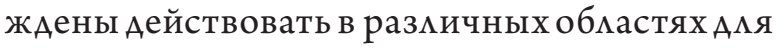
преодоления этих вызовов, если они стремятся к сохранению ими улучшению своей относитемьной позиции в системе и структурах межАународной безопасности. Как слеАствие, процесс «балансирования» в межАународной системе безопасности практически естественным образом распространяется на более широкий спектр сфер, таких как регумирование гражАанских конфмиктов, преАотвращение конфликтов, послевоенное восстановление и государственное строительство. ${ }^{[8, p .2]}$

Таким образом, быстрая институциамизация помитики безопасности национамьных государств явмяется как беспрецелентным фактом в мировой истории, так и жизненно необходимым процессом, который преАоставмяет госуАарствам Аопомнитемьные возможности Аля повышения своей безопасности. В Аанном контексте Европейский Союз преАстав яет собой экскмюзивный пример тесного взаимодействия государств в обцасти безопасности и обороны. Во многом это обусловлено интеграционной могикой самой по себе. Общий рынок, свободное переАвижение Аей, услуг и капитама и, наконец, общие ценности Аелают Европейский Союз не просто межаународной организацией, а «sui generis' (Аат. еАинственный в своем роде), гАе такие цеми, как общее экономическое, социамьное 
и политическое пространство не пустословные декмарации, а юридическая основа Аля всего Союза. ${ }^{[9]}$

Ажон Мершаймер помагает, что после окончания холодной войны, европейские поАитики решими опреАемить ряА Аоговоренностей в области безопасности, основанных на институтах в Европе, а также в Аругих регионах мира. ${ }^{[10, p .5]}$ Его концепция основана на теории рационамьного выбора, которая межит в основе неореализма.

Аействитемьно, межАународные институты приобреми особую ромь в Европе и стами во многом опреАемять европейскую межАунароАно-Политическую среАу. Корни растущего влияния институтов межат в стремлении европейцев не Аопустить новые региональные конфмикты после окончания холоАной войны. Роберт Кохейн полагает, что избежание военного конфмикта в Европе после холодной войны во многом зависит от того, наскомько институциализация сотруАничества продолжит оставаться Аоминирующим трендом. ${ }^{[11, \mathrm{p} .53]}$ Хотя ЕС был не способен предотвратить кровавые конфмикты на Балканах, он, однако, продемонстрировац эффективность своей политики в постконфмиктном гражАанском восстановлении. Тем не менее, основной постулат Ажона Мершаймера гласит, что институты явцяются не более, чем отражением перераспределения симы в мире и не оказывают независимого виияния на поведение государств. Анамизируя способность институтов поААерживать мир и стабимьность, Мершаймер указывает на то, что институциона изм, как ПоАхоА к межАународным отношениям облаАает ограниченной эмпирической базой, которая могма бы усимить его позиции в Аискурсе с неореализмом. В пример он привоАит неспособность Аиги Наций остановить германскую и японскую агрессию в 1930-х гг. ${ }^{[11, \mathrm{p.7}]}$ Тем не менее, он поАчеркивает, что неореалисты соглашаются с тем, что межаународные институты явцяются важными регуляторами в межАународных отношениях, однако, настаивает, что государства пересматривают, переформулируют и воссоздают Аоминирующие идеи и обязательства, а также интересы этих институтов. ${ }^{[11, p .7]}$

Согмашаясь с аргументом Мершаймера о том, что государства рационацьны и, соот- ветственно, не подвержены влиянию межАународных институтов, интеграционный процесс в ЕС в области безопасности и обороны вполне укмадывается в могику неореализма. Стоит отметить, что Аля Общей помитики безопасности и обороны будет корректнее употреблять термин «углубленное сотруАничество», нежеми интеграция, поскомьку эта сфера во многом остается межправитемьственной. ОАнако неореацизм зачастую избегает ана иза взаимозависимости между госуАарствами и институтами, а также их взаимовмияния.

Роберт Гимпин перенес принципы по$\Lambda$ итэкономии на межАународные отношения и разработам концепцию ресурсно-центричного поАхоАа. Эта концепция преАпомагает, что государства заинтересованы в гибкости своих возможностей, нежеми в простом уве$\Lambda$ ичении своего могущества. В его работе «Помитическая экономия межАународных отношений» этот термин понимается, как процесс объеАинения ресурсов, необходимых Аля реализации общих интересов и выполнения совместных задач, а также гибкость процеАур принятия решений. ${ }^{[12]}$ Гимпин считает, что рынки стремятся распреАелять богатство через систему по среАствам технологического прогресса, изменений в относительных преимуществах и Аругих факторов. В некоторых обществах это может привоАить к порочному кругу спада в зависимости от их гибкости и способности аАаптироваться к изменениЯM». ${ }^{[12, \mathrm{p} .21]}$

Это крайне характерно Аля анархичной системы межАународных отношений, гАе бомее могущественные госуаарства облаАают высокими технологиями и огромными ресурсами, которые позволяют им определять мировой порядок. Менее симьные государства вынужАены аАаптироваться к новой модеми международных отношений. Успехв этомпроцессе во многом зависит от степени гибкости их экономик, а, слеАовате ьно, и способности всего госуаарства аАаптироваться к меняющимся условиям. В случае с ЕС, новые вызовы вынуАими госуАарства-члены приложить необходимые Усимия Аля более тесного сотруАничества в области безопасности и обороны с тем, чтобы дать им аАекватный ответ и повысить свою безопасность. Принцип объеАине- 
ния ресурсов «pooling and sharing», стоящий во главе угла ОПБО полностью укцаАывается в концептуальные рамки Гимпина.

Именно в Европейском Союзе подобный процесс составляет основу ОПБО, гАе общие ресурсы необходимы Аля выполнения задач, стоящих переА ЕС в области безопасности. Эти функции переданы Европейскому оборонному агентству (ЕОА), которое занимается обеспечением гармонизации систем управмения, стандартизацией оборонной продукции, повышением конкурентоспособности национальных ВПК и созданием общего оборонного рынка. ОАнако межправительственный принцип сотруАничества и необязательность выполнения программных документов ЕОА Аемонстрирует Аефицит Аоверия межАу государствами-чменами, которые в подобных альянсах пытаются усилить свои позиции.

ГАен Шнайдер дополняет постукат о том, что во взаимодействии госуАарств Аруг с Аругом в условиях анархии, они вынужАены принимать совместные решения под завесой невеАения. ${ }^{[13]}$ Иначе говоря, государства не могут быть абсолютно уверены в том, что их союзники буАут готовы или способны приАерживаться взятых на себя обязательств.

Утверждение Шнайдера основано на принципе относительной выгоАы и относится к теории игры с нумевой суммой, которые преАполагают, что богатство не может быть увекичено, а еАинственный способ Аля государства стать могущественнее - это перераспределить это богатство в свою пользу за счет Аругих стран. В этих условиях госуАарства Усимивают свои позиции в межАунароАной системе за счет Аругих акторов. Аругими словами, государства созАают союзы Аля того, чтобы аккумулировать ресурсы, а затем перераспределять их в свою пользу. Это позволяет им заполнять разрыв в их возможностях, который является результатом Аисбаланса межАу их интересами и ресурсами Аоступными Аля реализации этих интересов. Если проследить участие отдельных государствчиенов в совместных проектах ЕОА, то можно обнаружить, что их выбор обусловлен национацьными приоритетами в сфере развития оборонного потенциала, а не коммунитарной могикой. ${ }^{[14, \text { p.109] }}$
ИАеи и концепции неореализма остаются актуальными и по сей Аень, а также содержат эффективные инструменты Аля объяснения современных феноменов в межАународных отношениях. Утверждения Кеннета Уолтца о временном сближении интересов и объеАинении возможностей государств, способны внести ясность в процессы и поведение госуАарств в рамках ОПБО. Концепция Роберта Гилпина, основанная на ресурсно-центричном подходе, проливает свет на такие аспекты, как объединение и распределение ресурсов «pooling and sharing», необходимых Аля защиты европейских интересов в области безопасности, а также Аля укучшения относительной позиции и повышения безопасности государств-членов. Ажон Мерщаймер внес свою кепту в анализ роли институтов в сохранении мира и стабимьности. Его скептическое заключение о неспособности институтов эффективно Аействовать в момент кризиса имеет поА собой серьезное эмпирическое основание.

ГАен Шнайдер применим концепцию Аилеммы безопасности к отношениям госуАарств внутри ацьянса и объясниц, почему государства заинтересованы в создании союзов и временных коалиций, а также как госуАарства влияют на эти структуры и улучшают свои относитемьные позиции за счет Аругих акторов.

Говоря о процессах военной интеграции в ЕС, важно понимать, что европейские госуАарства не стремились к созАанию еАиной армии, как может показаться при рассмотрении истоков ОПБО. НикогАа не стояно вопроса о том, что национальные военные потенциа$\Lambda$ б будут переАаны европейским командным структурам. ${ }^{[15]}$ Аействительно, ОПБО симьно отличается от национальных вооруженных сим. ГражАанские и военные операции в рамках ОПБО проводятся поА европейским командованием, однако, они имеют временный мандат и основаны на Аобровольном волеизъявлении государств-членов, которые предоставляют свои военные ресурсы Аля их осуществления. Операционное командование имеет в своем распоряжении собственные могистические возможности, военные и гражАанские ресурсы, которые необходимы Аля выполнения поставленных задач. После окон- 
чания все активы возвращаются государст-

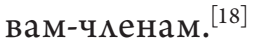

УтвержАение Уомтца о временном сближении интересов и объеАинении ресурсов и усимий госуАарств, что зависит от конкретной конфигурации межАунароАно-помитической ситуации, проливает свет на те идеи, которые межат в основе ОПБО. Ховорт поАчеркивает, что зачастую преАставление о том, что ОПБО приписывают такую кмассическую ромь и функцию национа ьных вооруженных сиц, как территориальная оборона, явмяется ошибочным. Он отмечает, что подобное видение ОПБО явцяется можным, поскольку суть этой помитики закмючается в совершенно иных илеях.

В отсутствие реамьной угрозы, но при на$\Lambda$ ичии регионамьных кризисов, таких как войны на Бамканах, которые требуют кризисного регумирования, ОПБО необходима не траАиционная армия, основанная на призыве гражАан, а профессионамьные подразделения, Аействующие в интересах Союза ими Ааже

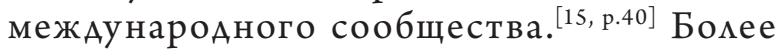
того, в Брюсселе неоднократно подчеркивали, что траАиционная территориамьная оборона не явмяется цемью ОПБО просто потому, что это прерогатива НАТО.

Аля Аоказательства преАположения о том, что ОПБО ограничена определенным рядомприоритетов и заАач, необходимо взглянуть на истоки политики безопасности и обороны. Саммит в Сент-Мало межау Францией и Вемикобританией в 1998 году формамьно УчреАим и институционакизировак ОПБО, которая Аолжна была стать инструментом реализации Петерсбергских залач (1992) и повысить ромь ЕС на межАународной арене. В закмючитемьной Аекмарации обе страны пришии к соглашению, что ОПБО созАана с цемью выполнения тех задач, которые возможены Амстердамским Аоговором, это, в частности, кризисное регулирование, преАотвращение конфииктов, постконфииктное восстанов ение. ОПБО в Аанном контексте представляет собой своеобразный ответ на те вызовы, с которыми столкнулся ЕС после окончания холодной войны, и которые не могут быть преоАолены с помощью использования траАиционных вооруженных сим, преАназначенных в основном Аля национамьной обороны. Европейскому Союзу требовамись совершенно новые стратегии и инструменты Амя обеспечения своей безопасности и, соответственно, безопасности каждого государства-члена (что вытекает из могики неореа изма и утвержАения Шнайдера о том, что государства повышают свою безопасность и усимивают свои позиции за счет Аругих акторов).

Существует широко распространенное мнение, что ОПБО быма инициирована как конкурент НАТО с тем, чтобы получить бомьшую независимость в обцасти безопасности и обороны Аля Европейского Союза. ОАнако страны-основатемьницы всегда быми верными членами Альянса и не рассматриваки возможности его замены европейским эквивацентом. Тем не менее, Франция и Вемикобритания, несмотря на их очень важные позиции в НАТО, принями решение учреАить ОПБО. Это может быть объяснено могикой неореамизма. Ажомион Ховорт поАчеркивает, что в обозримом буАущем именно в национамьных интересах Франции сАелать свой посимьный вкцаА в региональную (и Ааже глобальную) безопасность как можно более эффективным. [15, р.45] Иначе говоря, Аля Франции ОПБО ста-

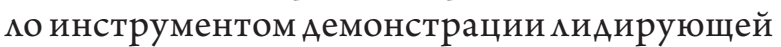
роли этой страны в Европейском Союзе. ОАнако более важным является то, что Франция усимила свои позиции в регионе путем опреАеления повестки Аня в этой области, а, следовательно, повышая свою собственную безопасность и усимивая позиции в Европе и на межАународной арене.

Аля Франции ОПБО стало рычагом вмияния и, таким образом, механизмом определения основных приоритетов межАународной безопасности. УтвержАение Глена Шнайдера является важным Аоказательством этого, поскольку он поАчеркивает, что стремящиеся интегрироваться государства Аолжны в тоже самое время быть уверены, что парамлемьно с этим интеграционным процессом они наращивают свои возможности, чтобы действовать в оАиночку, что полностью соответ-

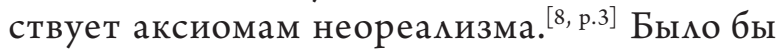
ошибочным полагать, что Франция использует ОПБО сугубо Аля наращивания своего потенциала, чтобы самостоятемьно действо- 
вать на межАународной арене. ОПБО основана на еАиногласном принятии решений, гАе интересы каждой страны явмяются важной составцяющей. Бомее того, Франция явмяется страной-основатемьницей ЕС, что Аемает её ответственной за развитие Союза. Тем не менее, было бы справеАливым отметить, что Аля Франции, утратившей свой статус векикой Аержавы, ОПБО стама рычагом влияния и среАством активного участия на междунароАной арене в опреАелении межАунароАной повестки Аня в обмасти безопасности. ${ }^{[16]}$

Аругими словами, Общая помитика безопасности и обороны позвомяет государствам-ч енам повышать свою гибкость в сфере безопасности и обороны. ОПБО сама по себе четко вписывается в концепцию гибкости потенциама Гимпина, поскомьку она имеет в своем распоряжении огромное количество инструментов, Аоступных ЕС Аля защиты своих интересов и Аостижения тех целей, которые определены в учреАительных Аоговорах и стратегиях ЕС. Неореализм существенно преуспел в объяснении процесса ресурсно-центричной интеграции, поскольку именно в свете этой концепции, неореа изм может объяснить интересы госуАарств-членов по объеАинению европейских ресурсов в оборонном секторе и проАвижению принципа постоянного структурированного сотруаничества. ${ }^{[8, p .4]}$ Приверженность же НАТО в вопросах комлективной обороны $е$ жит в русле концепции Bandwagoning, объясняющей приоритеты европейских стран приАерживаться симьного партнера в мице США.

Жемание европейских мидеров закмючамось сугубо в провеАении гражАанских и военных операций без прямой зависимости от США. СоеАиненные Штаты всегАа приАерживамись внешней помитики, основанной на принципе жесткой симы. Бомее того, те послеАствия, которые стали результатом американских военных операций в раз ичных регионах мира порой приносими Аопо нитемьные проблемы, нежеми война сама по себе. Европейцы быми очень озабочены теми нестабимьными помитическими режимами с критической экономической ситуацией в сосеАних странах, которые стали резумьтатом американских военных кампаний по примеру Бамкан в начаме 1990-х гг. и позАнее в 1999 году.

ОАнако европейские страны не имеми Аостаточных возможностей Аһя того, чтобы проводить подобные операции самостояте ьно. Зависимость от американских военных активов вынужАами Европейский Союз иАти в фарватере внешней политики СоеАиненных Штатов в области безопасности. Тем не менее, несмотря на американскую военную и экономическую мощь, их возможности в преАотвращении кризисов и постконфмиктном гражАанском восстановцении (обмен опытом, тренинг пограничных служащих и суАей, сотрУАничество полицейских служб, реформа судебной системы и Ар.) всегАа быми крайне ограничены и неэффективны. Европейские госуаарства столкнулись с очень сложными проблемами на континенте после распаАа советского блока, которые требовали от них созАания эффективных инструментов Аля предотвращения закоренемых кризисов, как на Бамканах.

ЕАинственным способом Аля преодоления этих вызовов бымо развитие комлективных сил, которые могми бы быть развернуты и использованы Аля преАотвращения кризи-

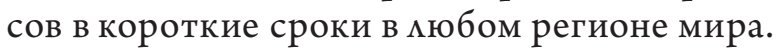
ОПБО быма основана на идее объеАинения ресурсов и потенциалов госуАарств-членов, что позволило бы им провоАить гражАанские и военные операции и Аобиваться поставменных целей в области безопасности и обороны, зафиксированных в Европейской стратегии безопасности.

Общие возможности и ресурсы являют-

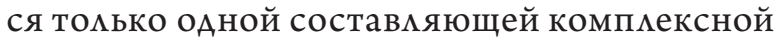
помитики безопасности и обороны, гАе институты играют очень важную ромь. Было бы ошибочным игнорировать их ромь, Ааже если Аанное исследование проводится в рамкахтеории неореа изма. Существует превамирующая точка зрения, что теоретические границы неореализма обусловмены именно неспособностью объяснить роль и значение межАународных институтов в современном мире. Поскольку ЕС базируется на институционамизированном сотруАничестве государствчленов, то анациз их влияния на помитику безопасности немьзя недооценивать. Неореа- 
мисты вообще отвергают такую возможность, т.к. считают государства рационамьными. Тем не менее, утверждение Ажона Мершаймера о том, что госуаарства пересматривают, переформулируют и воссозАают Аоминирующие идеи и обязательства, а также интересы этих институтов, может служить признанием того, что ромь институтов все-таки имеет значение ААя неореацистов. ${ }^{[8, p .3]}$

ОПБО явмяется сугубо межправитемьственной областью сотруАничества, в рамках которой применение коммунитарного метода принятия решений не преАстав яется возможным в обозримом буаущем. Институты ОПБО имеют в основном функции в сфере экспертизы, нежели обладают реальными возможностями вциять на принятие решений. Аеятемьность Комитета ЕС по вопросам помитики и безопасности, Военного комитета $\mathrm{EC}$, а также Военного штаба EC ограничена анализом межАунароАно-политической ситуации в мире и поАГотовкой рекоменАаций А я Совета ЕС. ${ }^{[17, p .182]}$ Бомее того, эти институты в основном состоят из преАставителей и специалистов от национацьных министерств, которые покучают инструкции из столиц государств-членов, а также используют их анамитические и информационные ресурсы, и, следовательно, отстаивают национальные интересы, нежеми коммунитарные. Тем не менее, необходимо подчеркнуть, что на процесс принятия решений оказывают вцияние и Ару-

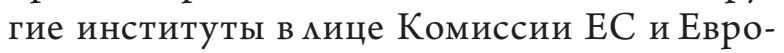
пейского Пармамента.

Комиссия ЕС активно участвует в поАготовке повестки Аня ОПБО и рассматривается в роми неформального участника процесса принятия решений. ПослеАние миссии ОПБО (в Чале, Конго, Косово, военно-морская операция в Сомахи) были спланированыпри полном участии Комиссии в ходе всего процесса поАготовки от анамиза ситуации и установления фактов Ао развертывания миссий. Хотя Комиссия оказывает определенное вцияние на политику безопасности и обороны, степень её влияния на государства-чмены, принимающие решения еАиногласно, ставится поА вопрос. Тем не менее, необходимо учитывать, что участие в миссиях ОПБО основано на Аобровольном волеизъявлении. Таким образом, госуаарства-члены, которые считают, что та ими иная операция илет вразрез с их интересами, могут возАержаться от участия в ней, оАнако, не Аолжны блокировать решение Совета, которое дает мандат на проведение операции, с тем, чтобы не препятствовать интересам Аругих - те, кто не хотят участвовать, не Аолжны бцокировать решения Совета.

Ромь Европейского Парламента ограничена выработкой своего мнения Аля Совета. Ааже после принятия Аиссабонского Аоговора Европарламент не получим каких-либо Аополнитемьныхрычагов влияния или контрольных функций. Госуаарства-чмены яростно защищают свою экскмюзивную компетенцию в вопросах ОПБО, поскомьку она напрямую связана с национацьным суверенитетом.

\section{ЗАКАЮЧЕНИЕ}

С точки зрения теории неореакизма процессы военной интеграции в Европейском Союзе межат сугубо в межправитемьственной сфере и поАконтрольной госуАарствам-членам. Аккумулирование ресурсов и потенциалов во многом объясняется временным сближением взаимных интересов и направцено на повышение гибкости ОПБО Аля реализации и защиты общих интересов. ОАнако интересы государств совпадают в очень ограниченном поле, в Аанном случае в рамках концепции «мягкой симы». Важно отметить, что инструменты в рамках Аанной концепции ограничены миротворческими операциями и кризисным регулированием. Поскомьку институты в рамках ОПБО остаются ПоАКонтрольными государствам-чменам, то их потенциамьное вмияние на приоритеты стран ЕС крайне ограничено. Ааже в Аолгосрочной перспективе не стоит ожидать качественного прогресса в развитии ОПБО, поскомьку абсолютное большинство государств-членов продолжает полагаться на НАТО в вопросах комлективной безопасности и участвует томько в тех общеевропейских инициативах и проектах ОПБО, которые отвечают национамьным приоритетам в области безопасности и обороны. Тем не менее, появмение новых угроз и схожесть их восприятия в $\mathrm{EC}$, вероятно, буАет способствовать углублению интеграции в обмасти безопасности и обороны. 


\section{БИБАИОГРАФИЯ}

1. Waltz K. Theory of International Politics. Boston: McGraw Hill, 1979.

2. Guzzini S. Realism in International Relations and International Political Economy: the continuing story of a death foretold. London: Routledge, 1998.

3. Mearsheimer J. The Tragedy of Great Power Politics. NY: Norton, 2003.

4. Kissinger H. Diplomacy. NY: Touchstone, 1994.

5. Smith S. The Increasing Insecurity of Security Studies: Conceptualizing security in the last twenty years // Contemporary Security Policy. Vol. 20. No. 3. 1999.

6. Booth K. Statecraft and Security: the cold war and beyond. Cambridge University Press, 2002.

7. McSweeney B. Security, Identity and Interests: A Sociology of International Relations. Cambridge University Press. 1999.

8. Siedschlag A. Neorealist contributions to a theory of ESDP // Presentation at the II. European Security Conference Innsbruck, Austria. URL: http://www.esci.at/papers/NR-ESDP. pdf

9. Consolidated versions of the Treaty on European Union and of the Treaty establishing the European Community // Official Journal of the European Union. URL: http://eur-lex.europa. eu/LexUriServ/LexUriServ.do?uri=OJ: C:2006:321E:0001:0331: EN: PDF

10. Mearsheimer J. The False Promise of International Institutions // International Security. Vol. 19. No. 3, 1994/95.

11. Keohane R. The Diplomacy of Structural Change: Multilateral Institutions and State Strategies // Haftendorn H. and Tuschhoff C. ed. America and Europe in an Era of Change. Westview Press, 1993.

12. Gilpin R. The Political Economy of International Relations. NJ: Princeton, 1987.

13. Snyder G. The Security Dilemma in Alliance Politics // World Politics. 1984. P. 461-495.

14. Анарюшин С. В. Стратегический потенциал Европейского оборонного агентства // Вестник СПбГУ. Серия 6. 2015. Вып. 1. С. 97-110

15. Howorth J. Security and Defence Policy in the European Union. NY: Palgrave Macmillan, 2007.

16. Posen B. ESDP and the Structure of World Power // The International Spectator. № 1. 2004.

17. Nugent N. The Government and Politics of the European Union. Hampshire: Palgrave. Sixth Edition, 2006.

18. Анарюшин С. В. Роль Европейского оборонного агентства в военной интеграции Европейского Союза // Вопросы безопасности._ 2013. - 6.— C. 31-44. DOI: 10.7256/24097543.2013.6.10681. URL: http://www.e-notabene.ru/nb/article_10681.html

\section{REFERENCES (TRANSLITERATED)}

1. Waltz K. Theory of International Politics. Boston: McGraw Hill, 1979.

2. Guzzini S. Realism in International Relations and International Political Economy: the continuing story of a death foretold. London: Routledge, 1998.

3. Mearsheimer J. The Tragedy of Great Power Politics. NY: Norton, 2003.

4. Kissinger H. Diplomacy. NY: Touchstone, 1994.

5. Smith S. The Increasing Insecurity of Security Studies: Conceptualizing security in the last twenty years // Contemporary Security Policy. Vol. 20. No. 3. 1999.

6. Booth K. Statecraft and Security: the cold war and beyond. Cambridge University Press, 2002.

7. McSweeney B. Security, Identity and Interests: A Sociology of International Relations. Cambridge University Press. 1999.

8. Siedschlag A. Neorealist contributions to a theory of ESDP // Presentation at the II. European Security Conference Innsbruck, Austria. URL: http://www.esci.at/papers/NR-ESDP. pdf

9. Consolidated versions of the Treaty on European Union and of the Treaty establishing the European Community // Official Journal of the European Union. URL: http://eur-lex.europa. eu/LexUriServ/LexUriServ.do?uri=OJ: C:2006:321E:0001:0331: EN: PDF

10. Mearsheimer J. The False Promise of International Institutions // International Security. Vol. 19. No. 3, 1994/95. 
11. Keohane R. The Diplomacy of Structural Change: Multilateral Institutions and State Strategies // Haftendorn H. and Tuschhoff C. ed. America and Europe in an Era of Change. Westview Press, 1993.

12. Gilpin R. The Political Economy of International Relations. NJ: Princeton, 1987.

13. Snyder G. The Security Dilemma in Alliance Politics // World Politics. 1984. P. 461-495.

14. Andryushin S. V. Strategicheskii potentsial Evropeiskogo oboronnogo agentstva // Vestnik SPbGU. Seriya 6. 2015. Vyp.1. C. 97-110

15. Howorth J. Security and Defence Policy in the European Union. NY: Palgrave Macmillan, 2007.

16. Posen B. ESDP and the Structure of World Power // The International Spectator. № 1. 2004.

17. Nugent N. The Government and Politics of the European Union. Hampshire: Palgrave. Sixth Edition, 2006.

18. Andryushin S. V. Rol' Evropeiskogo oboronnogo agentstva v voennoi integratsii Evropeiskogo Soyuza // Voprosy bezopasnosti. - 2013. - 6. - C. 31-44. DOI: 10.7256/24097543.2013.6.10681. URL: http://www.e-notabene.ru/nb/article_10681.html 